\title{
DOSSIER
}

\section{Inleiding: het correctief referendum}

\author{
Tamara Metze*
}

\section{Inleiding Dossier: het correctief referendum}

In dit Dossier bediscussiëren Frank Hendriks, Tom van der Meer en Kristof Jacobs het in januari 2021 door de Eerste Kamer aangenomen initiatiefvoorstel van SP'er Ronald Raak om in de Grondwet bepalingen op te nemen voor het bindend correctief referendum. Het is nog geen gelopen race en er gaan nog tweede lezingen komen in de Tweede en Eerste Kamer. De auteurs bewerkten voor dit Dossier hun eerdere advies aan de Eerste Kamer.

De focus van de auteurs ligt op de opgeschroefde uitkomstdrempel: een percentage van voorstemmers en tegenstemmers dat gehaald moet worden voor een geldige referendumuitslag. Dit is anders dan een opkomstdrempel, waarbij het totale aantal uitgebrachte stemmen telt. De uitkomstdrempel komt in het huidige voorstel op zo'n 40 procent uit,. De drie betogen vanuit verschillende invalshoeken dat dit een te hoge drempel is.

Hendriks bekijkt deze discussie vanuit de functies van het referendum als een noodrem en stok achter de deur. Als er een te hoge uitkomstdrempel is, dan kunnen deze functies niet vervuld worden en heeft een correctief referendum weinig zin.

Van der Meer geeft daarbij ook ter overweging het probleem dat wanneer het opkomst- of uitkomstpercentage te laag is, het referendum weinig representatief kan zijn. Hij laat zien dat het huidige waarschijnlijke percentage van ongeveer 40 procent onnodig hoog is vanuit het oogpunt van representativiteit van uitkomsten.

Tot slot laat Jacobs zien wat de feitelijke haalbaarheid is van een uitkomstdrempel gelijk aan de helft van de opkomst bij de Tweede Kamerverkiezingen (zo'n 40 procent dus). Aan de hand van ervaringen uit het buitenland is ook zijn inschatting dat 40 procent te hoog is. Bovendien is zijn punt dat als de uitkomstdrempel zo hoog is, dit voor mensen een incentive geeft om niet te gaan stemmen - omdat de kans groot is dat de drempel niet gehaald wordt - en de uitslag dus niet telt. Dat is niet goed voor de legitimiteit van een instrument als het correctief referendum.

* Dr. Tamara Metze is universitair hoofddocent bij de leerstoelgroep Bestuur en Beleid aan de Wageningen Universiteit en voorzitter van de redactie van Beleid en Maatschappij. 